\title{
A study of the effect of aerosols on tropospheric ozone through meteorology feedbacks over China
}

(a) 1.5-m temperature $\left({ }^{\circ} \mathrm{C}\right)$

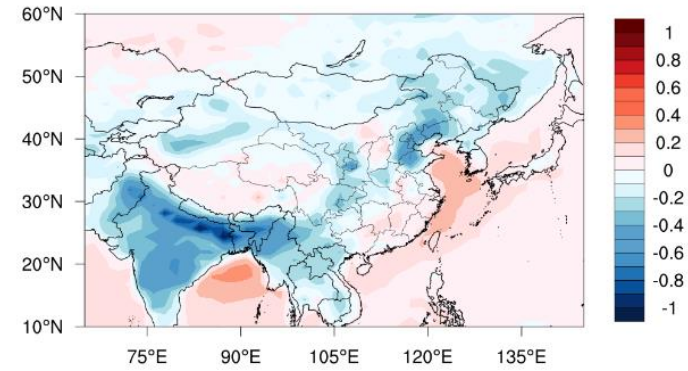

(b) $1.5-\mathrm{m}$ relative humidity $(\%)$

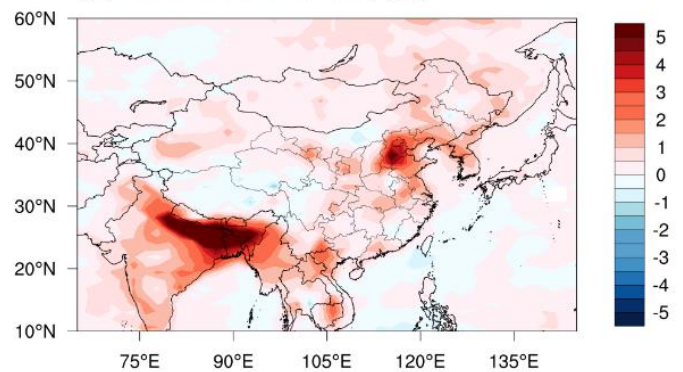

Supplementary Figure S1: Changes in (a) temperature at $1.5 \mathrm{~m}\left({ }^{\circ} \mathrm{C}\right)$ and $(\mathrm{b})$ relative humidity $(\%)$ at $1.5 \mathrm{~m}$ due to aerosol direct radiative effect. Differences are calculated as the annual mean of $\mathbf{E X P}_{\text {radon }}$ minus EXPradoff.

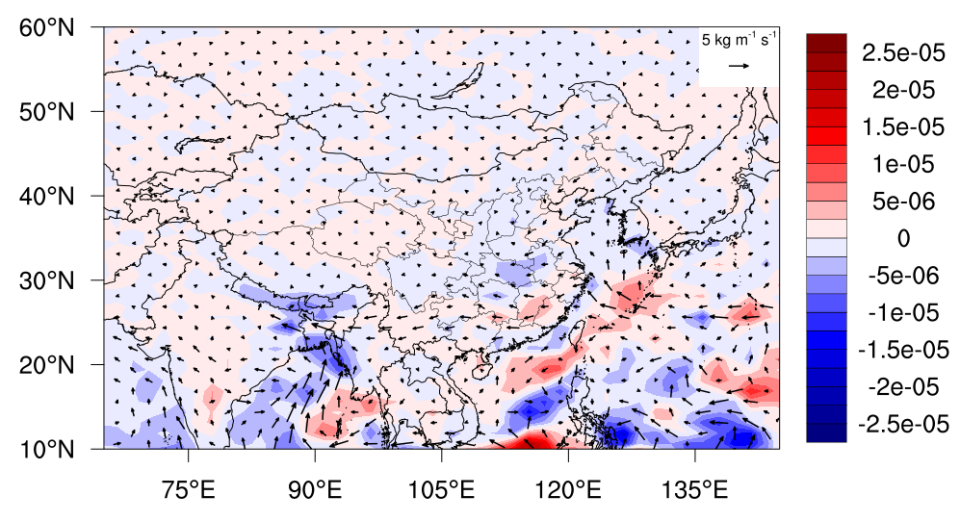

Supplementary Figure S2: Changes in annual mean total column horizontal water vapor flux (vector) and its divergence (shadow) due to aerosol direct radiative effect. Differences are calculated as the annual mean of EXPradon minus EXP radoff. 
(a) $\mathrm{NO}+\mathrm{O}_{3}->\mathrm{NO}_{2}+\mathrm{O}_{2}$ (moles grid $\left.^{-1} \mathrm{~s}^{-1}\right)$

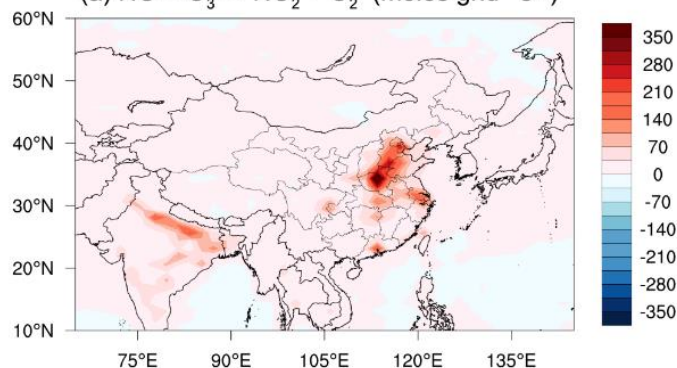

(c) $\mathrm{O}^{3} \mathrm{P}+\mathrm{O}_{2}+\mathrm{M}->\mathrm{O}_{3}+\mathrm{M}\left(\right.$ moles grid $\left.^{-1} \mathrm{~s}^{-1}\right)$

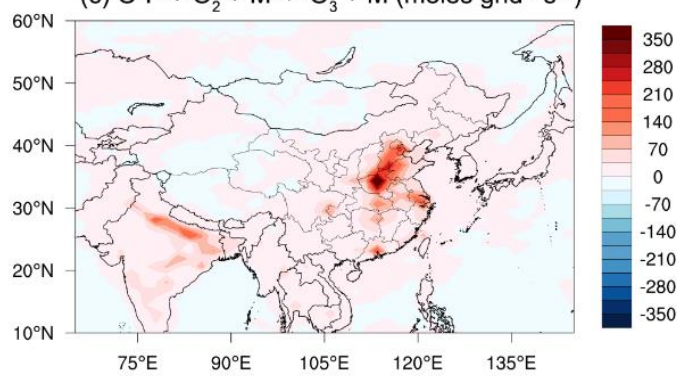

(b) $\mathrm{NO}+\mathrm{O}_{3}->\mathrm{NO}_{2}+\mathrm{O}_{2}(\%)$

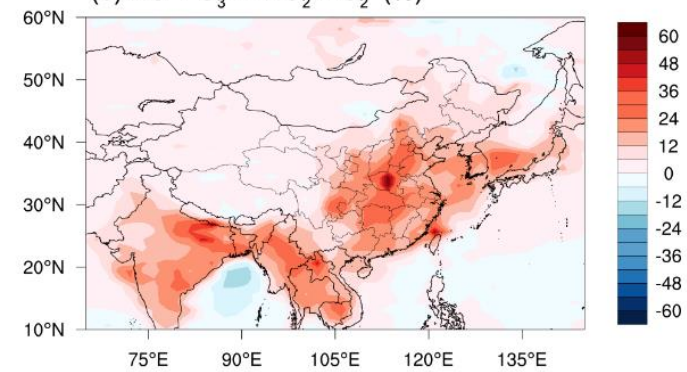

(d) $\mathrm{O}^{3} \mathrm{P}+\mathrm{O}_{2}+\mathrm{M}->\mathrm{O}_{3}+\mathrm{M}(\%)$

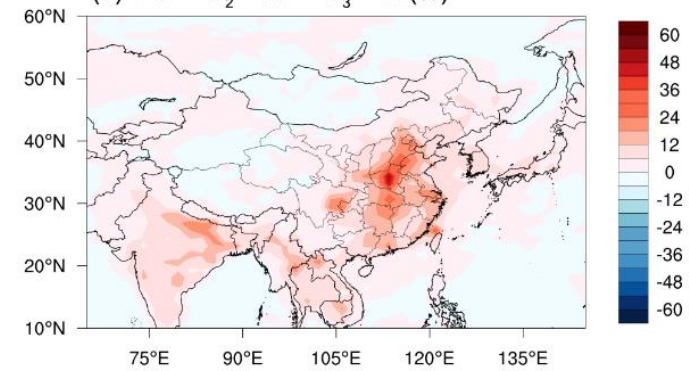

Supplementary Figure S3: Changes in reaction flux due to aerosol direct radiative effect, (a,b) $\mathrm{O}_{3}$ loss: NO + $\mathrm{O}_{3}->\mathrm{NO}_{2}+\mathrm{O}_{2} ;(\mathrm{c}, \mathrm{d}) \mathrm{O}_{3}$ production: $\mathrm{O}^{3} \mathrm{P}+\mathrm{O}_{2}+\mathrm{M}->\mathrm{O}_{3}+\mathrm{M}$. The left panels show the reaction flux changes in moles grid $^{-1} \mathrm{~s}^{-1}$, which are calculated as EXPradon minus EXPradoff. The right panels show the percentage changes, which are calculated as $\left(\mathbf{E X P} P_{\text {radon- }}-\mathbf{E X P} P_{\text {radoff }}\right) / \mathbf{E X P}_{\text {radoff. }}$ 